\title{
CHST11 Gene
}

National Cancer Institute

\section{Source}

National Cancer Institute. CHST11 Gene. NCI Thesaurus. Code C143061.

This gene plays a role in the metabolism of chondroitin sulfate. 